\title{
PERLINDUNGAN SAKSI DAN KORBAN DALAM PERSPEKTIF HAK ASASI MANUSIA PADA PROSES PERADILAN PIDANA
}

\author{
Abdul Salam Siku \\ Universitas Negeri 45 Makassar
}

\begin{abstract}
ABSTRAK
Pada hakikatnya perlindungan saksi dan korban adalah merupakan pemberian seperangkat hak dan tanggung jawab yang dapat dimanfaatkan dalam proses peradilan pidana demi tercapainya kebenaran materiil. Saksi dan korban merupakan unsur yang sangat menentukan dalam mewujudkan sistem peradilan yang cepat, sederhana dan biaya ringan. Namun, keberadaan saksi dan korban dalam proses peradilan pidana selama ini kurang mendapat perhatian masyarakat dan penegak hukum, akibatnya banyak kasus yang tidak terungkap dan tidak dapat diselesaikan sesuai prosedur hokum yang berlaku disebabkan oleh saksi dan korban yang takut memberikan kesaksian karena tidak merasa aman dalam kehidupannya. Perlindungan hukum terhadap saksi dan korban dalam proses peradilan pidana tidak hanya diperlukan pada saat sebelu saksi dan korban memberikan keterangannya di muka persidangan, akan tetapi juga sangat diperlukan sesudah memberikan keterangan di mukan persidangan, hal ini dimaksudkan untuk memberikan rasa aman dan percaya diri pada saksi dan korban. Manifestasi ketidakpuasan masyarakat terhadap perlakuan pihak yang mewakilinya, kemudian muncul dalam berbagai bentuk mulai dari tindakan pelemparan sepatu pada hakim, perusakan gedung pengadilan, sampai pada tindakan main hakim sendiri, yang akhir-akhir ini marak terjadi. Tindakan-tindakan anarki yang dilakukan masyarakat tersebut berpangkal tolak dati perasaan tidak puas, perasaan diperlakukan tidak adil dalam diri masyarakat.
\end{abstract}

Kata kunci: Perlindungan Hukum, Saksi, Korban

\section{A. PENDAHULUAN}

Negara Indonesia adalah negara yang didasarkan atas hukum, tidak didasarkan atas kekuasaan belaka, hal ini mengandung pengertian bahwa negara, termasuk di dalamnya pemerintah dan lembaga-lembaga negara yang lain dalam melaksanakan tindakan apapun harus dilandasi oleh hukum atau harus dapat dipertanggung jawabkan secara hukum. Oleh karena itu perlu adanya pembangunan hukum yang pada hakekatnya pembangunan hukum tersebut adalah sebagai upaya untuk menegakkan keadilan, kebenaran dan ketertiban di negara Indonesia yang berdasarkan Pancasila dan UndangUndang Dasar Negara Republik Indonesia Tahun 1945.
Pembangunan nasional yang mengikutsertakan masyarakat senantiasa dapat menumbuhkan kesadaran hukum masyarakatnya, sehingga dapat mengurangi timbulnya berbagai bentuk kejahatan. Dalam suatu proses peradilan pidana guna mengungkap suatu tindak pidana yang terjadi, tidak bisa lepas dari peran serta saksi dan korban tindak pidana itu sendiri dalam memberikan kesaksian. Dalam usaha penegakan hukum pidana di tanah air acap kali terganjal oleh susahnya memperoleh alat bukti dalam proses peradilan pidana berupa keterangan saksi termasuk di dalamnya saksi dari korban tindak pidana itu sendiri. Para saksi kerap kali mengalami intimidasi, ancaman, tekanan dari pihak pelaku atau pihak tertentu 
yang tidak ingin kejahatannya terbongkar. Akibatnya, para saksi tidak bisa secara leluasa menyampaikan informasi yang sebenarnya tentang kejadian yang mereka dengar, lihat, dan/atau alami sendiri.

Keberhasilan suatu proses peradilan pidana sangat bergantung pada alat bukti yang berhasil diungkap atau ditemukan. Dalam proses persidangan, terutama yang berkenaan dengan saksi, banyak kasus yang tidak terungkap akibat tidak adanya saksi yang dapat mendukung tugas penegak hukum. Padahal, adanya saksi dan korban merupakan unsur yang sangat menentukan dalam proses peradilan pidana. Keberadaan saksi dan korban dalam proses peradilan pidana selama ini kurang mendapat perhatian masyarakat dan penegak hukum. Kasuskasus yang tidak terungkap dan tidak terselesaikan banyak disebabkan oleh saksi dan korban takut memberikan kesaksian kepada penegak hukum karena mendapat ancaman dari pihak tertentu.

Tidak dapat dipungkiri, bahwa selama ini yang sering menjadi perhatian dalam suatu proses peradilan hanyalah orang yang melanggar atau pelaku tindak pidana saja. Kepada pelaku tindak pidana diberikan seperangkat hak untuk membela dirinya melalui proses hukum yang adil (due process of law). Kepedulian yang demikian besar kepada tersangka/pelaku tindak pidana menimbulkan persepsi bahwa the pendulum has swung too far, karena seolah-olah telah mengabaikan pihak lain yang terlibat dalam proses peradilan pidana, terutama saksi termasuk didalamnya saksi korban.(http:jelita249.blogspot..com/20 09/08/optimalisasi-kinerjalembaga.html) Sebagai upaya menumbuhkan partisipasi masyarakat untuk mengungkap tindak pidana, pemerintah menganggap perlu untuk menciptakan iklim yang kondusif dengan cara memberikan perlindungan hukum dan keamanan kepada setiap orang yang mengetahui atau menemukan suatu hal yang dapat membantu mengungkap tindak pidana yang telah terjadi dan melaporkan hal tersebut kepada penegak hukum.

Perlindungan saksi dan korban dalam proses peradilan pidana di Indonesia telah diatur secara khusus dalam undang-undang, yaitu Undangundang Nomor 13 Tahun 2006 tentang Perlindungan Saksi dan Korban yang dimuat dalam Lembaran Negara Republik Indonesia Tahun 2006 Nomor 64, yang disahkan berlaku sejak tanggal 11 Agustus 2006

Disebutkan dalam penjelasan Undang-Undang Nomor 13 Tahun 2006, bahwa berdasarkan asas kesamaan di depan hukum (equality before the law) yang menjadi salah satu ciri negara hukum, saksi dan korban dalam proses peradilan pidana harus diberi jaminan perlindungan hukum.

\section{B. PENGATURAN TENTANG PERLINDUNGAN SAKSI DAN KORBAN}

Perlindungan saksi dan korban pada prinsipnya harus merupakan pemberian seperangkat hak yang dapat dimanfaatkan mereka dalam posisinya di proses peradilan pidana. Perlindungan ini merupakan salah satu bentuk penghargaan atas kontribusi mereka dalam proses peradilan pidana demi untuk mencapai kebenaran materiil.

Dengan diundangkannya Undang-Undang Nomor 13 Tahun 2006 Tentang Perlindungan Saksi dan Korban dalam Lembaran Negara Republik Indonesia Tahun 2006 Nomor 64, walaupun belum maksimal, namun perhatian terhadap saksi dan korban telah mulai mendapat pengaturan, yaitu sebagaimana tertuang dalam Pasal 5 Undang-Undang Nomor 13 Tahun 2006, yang selengkap berbunyi: 
(1) Seorang Saksi dan Korban berhak:

a. Memperoleh perlindungan atas keamanan pribadi, keluarga dan harta bendanya, serta bebas dari ancaman yang berkenaan dengan kesaksiannya yang akan, sedang, atau telah diberikannya;

b. Ikut serta dalam proses memilih dan menentukan bentuk perlindungan dan dukungan keamanan;

c. Memberikan keterangan tanpa tekanan;

d. Mendapat penerjemah;

e. Bebas dari pertanyaan yang menjerat;

f. Mendapatkan informasi mengenai perkembangan kasus;

g. Mendapat informasi mengenai putusan pengadilan;

h. Mengetahui dalam hal terpidana dibebaskan;

i. Mendapat identitas baru;

j. Mendapat tempat kediaman baru;

k. Memperoleh penggantian biayatransportasi sesuai dengan kebutuhan;

1. Mendapat nasihat hukum; dan/atau

m. Memperoleh bantuan biaya hidup sementara sampai batas waktu perlindungan berakhir.

(2) Hak sebagaimana dimaksud pada ayat (1) diberikan kepada saksi dan/atau korban tindak pidana dalam kasus-kasus tertentu sesuai dengan keputusan LPSK.

KUHAP memang tidak mempunyai ketentuan yang secara khusus, rinci dan lengkap tentang perlindungan hukum terhadap saksi dan korban dalam proses peradillan pidana. Akan tetapi bukan berarti bahwa dalam Kitab Undang-Undang Hukum Acara Pidana kita tidak ada ketentuan semacam itu. Adapun beberapa pasal dalam KUHAP yang dianggap memberikan perlindungan pada saksi dan korban adalah:

1. Pasal 117 ayat (1): Keterangan tersangka dan atau saksi kepada penyidik diberikan tanpa tekanan dari siapapun dan atau dalam bentuk apapun.

2. Pasal 118: keterangan tersangka dan atau saksi dicatat dalam berita acara yang ditandatangani oleh penyidik, dan oleh yang memberi keterangan itu setelah mereka menyetujuinya.

3. Pasal 166: Pertanyaan yang bersifat menjerat tidak boleh diajukan kepada terdakwa maupun kepada saksi.

4. Pasal 177: Jika terdakwa atau saksi tidak paham bahasa Indonesia, hakim ketua sidang menunjuk seorang juru bahasa yang bersumpah atau berjanji akan menterjemahkan dengan benar semua yang harus diterjemahkan.

5. Pasal 178: Jika terdakwa atau saksi bisu dan atau tuli serta tidak dapat membaca dan menulis, hakim ketua sidang mengangkat sebagai penterjemah orang yang pandai bergaul dengan terdakwa.atau saksi itu.

6. Pasal 229: Saksi atau ahli yang telah hadir memenuhi panggilan dalam rangka memberikan keterangan di semua tingkat pemeriksaan, berhak mendapat penggantian biaya menurut aturan perundang-undangan yang berlaku.

7. Pasal 98: Korban suatu tindak pidana dapat mengajukan ganti kerugian pada terdakwa yang terbukti bersalah menyebabkan kerugian baginya, melalui proses penggabungan perkara pidana dan perdata.

Disamping aturan-aturan dalam KUHAP, maka sejak tahun 1997 beberapa undang-undang tindak pidana khusus di luar KUHP, mencantumkan beberapa pasal yang bertujuan untuk memberikan perlindungan pada saksi. 
Undang-Undang Narkotika, UndangUndang Psikotropika, Undang-Undang Pemberantasan Tindak Pidana Korupsi, Undang-Undang Pengadilan HAM, Undang-Undang Tindak Pidana Pencucian Uang, dan Undang-Undang Pemberantasan Tindak Pidana Terorisme dalam ketentuannya mencantumkan pasal yang melarang dikemukakannya identitas pelapor (saksi). Selain itu dalam Pasal 42 Undang-Undang Tindak Pidana Pencucian Uang juga dicantumkan secara tegas bahwa negara berkewajiban untuk memberikan perlindungan khusus bagi setiap orang yang memberikan kesaksian agar terhindar dari kemungkinan ancaman yang membahayakan diri, jiwa, dan/atau hartanya termasuk keluarganya.

Pasal 34 Undang-Undang Pemberantasan Tindak Pidana Terorisme, bahkan secara lebih rinci menetapkan bentuk perlindungan yang wajib diberikan oleh negara, baik sebelum, selama, maupun sesudah proses pemeriksaan perkara kepada saksi, yaitu perlindungan atas keamanan pribadi dari ancaman fisik dan mental; kerahasiaan identitas saksi; pemberian keterangan pada saat pemeriksaan di sidang pengadilan tanpa bertatap muka dengan terdakwa.

Adanya ketentuan-ketentuan semacam itu tentunya merupakan suatu langkah maju dan perwujudan dari timbulnya kesadaran bahwa dalam proses peradilan bukan hanya tersangka/terdakwa yang periu mendapat perlindungan, meskipun masih perlu dipantau apakah ketentuan ini pada akhirnya dapat diimplementasikan, karena masih dibutuhkan adanya Peraturan Pemerintah (PP) untuk melaksanakan ketentuan pasal undang-undang tersebut.

Berbeda dengan UndangUndang Tindak Pidana Pencucian uang yang masih harus menunggu $\mathrm{PP}$ untuk implementasinya, untuk Undang-Undang Pengadilan HAM telah dikeluarkan PP No. 2 tahun 2002 yang berisi tata cara perlindungan terhadap korban dan saksi dalam pelanggaran hak asasi manusia yang berat. PP ini merupakan peraturan pelaksanaan dari pasal 34 ayat (3) UU No. 26 Tahun 2000 tentang Pengadilan HAM. Dalam penjelasan umum dikatakan bahwa latar belakang dibuatnya PP ini adalah untuk memberikan perlindungan baik fisik maupun mental kepada korban maupun saksi dari ancaman, gangguan, teror, atau kekerasan dari pihak manapun. Dengan jaminan itu diharapkan mereka dapat memberikan keterangan secara benar, sehingga proses peradilan dapat dilaksanakan dengan baik. Bentuk-bentuk perlindungan yang dapat diberikan menurut Pasal 2 PP ini meliputi:

1. Perlindungan atas keamanan pribadi korban atau saksi dan ancaman fisik dan mental;

2. Perahasiaan identitas korban atau saksi;

3. Pemberian keterangan pada saat pemeriksaan di sidang pengadilan tanpa bertatap muka tanpa bertatap muka dengan tersangka.

Perlindungan yang dijamin melalui PP ini ternyata tidak berbeda dengan yang tercantum dalam UndangUndang Pemberantasan Tindak Pidana Pencucian Uang. Perlindunganperlindungan itu memang merupakan sebagian hak-hak yang sudah diatur dalam Undang-Undang tentang Perlindungan Saksi dan Korban. Beberapa hal yang juga diusulkan untuk saksi dan korban pada tindak pidana yang dilakukan dengan kekerasan, tindak pidana narkotika dan psikotropika, tindak pidana korupsi, pelanggaran HAM berat adalah hak untuk mendapatkan identitas baru dan hak atas relokasi. Dalam berbagai seminar dan pertemuan ilmiah lainnya 
yang diselenggarakan untuk membahas tentang pelaksanaan undang-undang Perlindungan Saksi dan Korban, memang masih timbul pertanyaan akan efektivitas dua hak ini disebabkan implikasi dan konsekuensi yang mungkin timbul dari diberikannya kedua jenis hak tersebut.

Apabila bagi saksi dan korban dalam beberapa tindak pidana khusus telah ada jaminan perlindungannya dalam UU, bagaimana halnya dengan saksi dan korban dalam tindak pidana umum, seperti pembunuhan, perkosaan, penganiayaan, bahkan pencemaran nama baik? Apakah mereka tidak berhak atas perlindungan yang sama. Pertanyaan ini akan terjawab dalam Pasal 2 Undang-Undang Perlindungan Saksi dan korban yang berbunyi:

Undang-undang inimemberikan perlindungan pada saksi dan korban dalam semua tahap proses peradilan pidana dalam lingkungan peradilan

Selanjutnya Pasal 3 Undang_undang Perlindungan Saksi dan korban berbunyi;

Perlindungan saksi dan korban berasaskan pada:

a. Penghargaan atas harkat dan martabat manusia

b. Rasa aman

c. keadilan

d. tidak diskriminatif

e. kepastian hukum

Berdasarkan

ketentuan tersebut maka dapat dikemukakan bahwa baik saksi dan korban dalam tindak pidana khusus maupun saksi dan korban dalam tindak pidana umum harus mendapat perlindungan hukum yang sama, sehingga tidak terjadi diskriminasi dalam perlindungan saksi dan korban.

\section{KEDUDUKAN SAKSI DAN KORBAN DALAM PROSES PERADILAN PIDANA}

Herbert L. Packer dalam bukunya yang terkenal "The Limits of the
Criminal Sanction (1968); mengemukakan bahwa ada dua model dalam Sistem Peradilan Pidana, yaitu Crime Control Model (CCM), dan Due Process Model (DPM). Kedua model tersebut di atas yang disoroti adalah sebuah usaha yang memberi petunjuk operasional terhadap kompleksnyanilainilai yang mendasarinya. Hukum pidana sebagaimana disarankan oleh Packer adalah untuk menentukan dua sistem nilai yang berlawanan, yakni suatu ketegangan dari yang terlibat dalam hal ini, yaitu para pembuat undang-undang, hakim polisi, pengacara dan penuntut umum, dimana masing-masing nilai menjadi gambaran bagi pihak yang terlibat dan selalu bertentangan pada setiap gerak sesuai dengan waktu dan tokoh yang diwakili pada tiap proses kriminal itu. Adapun nilai-nilai tersebut merupakan suatu alat bantu analisis dan pertentangan kedua model itu tidak absolut dan merupakan abstraksi dari masyarakat Amerika, serta merupakan suatu cara pemeriksaan tentang bagaimana suatu perundang-undangan itu berjalan atau diterapkan dalam Peradilan Pidana di Amerika (Packer, 1968: 197).

Kedua model tersebut di atas oleh Packer bukanlah label dari Das Sollen dan Das Sein, tetapi diartikan sebagai suatu hal yang mana baik dan tidak baik atau ideal, kedua model ini sebagai cara untuk memudahkan, bila membicarakan tentang tata kerja suatu proses yang dalam pelaksanaan seharihari melibatkan suatu rangkaian yang terjadi dalam proses peradilan pidana. Adapun nilai dasar dari kedua model itu yakni bahwa peraturan perundangundangan itu harus ada terlebih dahulu perumusannya sebagai suatu tindak pidana yang diancam dengan pidana setiap pelanggarannya. Dan sebelum seseorang dinyatakan bersalah melakukan tindak pidana, maka peraturan perundang-undangan yang dibuat itu menjadi dasar utama bagi penegak hukum dalam penerapannya. 
Jika ternyata terjadi pelanggaran terhadap ketentuan Perundang-undangan itu, maka pelaku tindak pidana harus diproses oleh pejabat yang diberi kewenangan untuk mengabil tindakan hukum sejak tahap pengangkatan, penahanan, sampai diadakan penuntutan di pengadilan. Kemudian dari kewenangan yang diberikan itu oleh Perundang-undangan, maka aparat penegak hukum dalam mengabil tindakannya terhadap tersangka harus sesuai dengan peraturan perundangundangan yang berlaku tersebut. Hak tersangka harus dihormati dan perlakuan terhadapnya tidak boleh sewenangwenang.

Hal yang penting dikemukakan oleh Packer selain beberapa asas dalam pelaksanaan sistem peradilan pidana, yaitu tersangka tidak dibenarkan untuk dijadikan sebagai obyek pemeriksaan semata-mata, oleh karenanya Jaksa mempunyai kewajiban untuk membuktikan kesalahan terdakwa, karena berkenaan dengan posisinya sebagai Penuntut Umum.

Adapun ciri khas dari crime control model itu ialah sangat mengandalkan "Profesionalisme" untuk mencapai effisiensi yang tinggi. Penanganannya dengan memakai atau menggunakan Assembly Line (ban berjalan). Karena profesional yang merupakan sifatnya, maka peraturan yang bersifat formal sering dilanggar, dan kadang-kadang untuk mendapatkan barang bukti, para profesionalis ini memaksakan cara-cara illegal untuk tujuan cepat dan effisiensi.

Sehingga untuk menghindari hambatan dari proses pidana itu maka kewenangn kebijakan dari penegak hukum itu seringkali diperluas. Dan dalam kenyataannya bahwa Crime Control Model ini sering dipertentangkan sebagai kurang manusiawi dan tidak menghormati hak asasi manusia.

Kemudian model yang kedua yakni Due Process Model dengan ciri- ciri selalu menganggap penting adanya refresif kejahatan, yaitu tahap ajudicatif (dalam sidang pengadilan harus ditentukan salah tidaknya tersangka), atas dasar legal guilt. Kemudian selalu mengadakan chek and recheck (obstacle couse) dan hal ini harus diuji menurut peraturan. Ciri berikutnya adalah menghormati undang-undang. Kemudian menempatkan kedudukan yang sama bagi setiap orang di depan hukum (Quality Control). Sehingga model ini dikatakan orang lebih manusiawi dan menghormati hak asasi manusia.

Pada Due Process Model, sangat diperlukan peranan Bantuan Hukum yang dalam hal ini ialah pengacara untuk mendampingi tersangka sejak di tingkat penahanan, penangkapan, maupun tentunya di pengadilan. Sehingga para tersangka merasa tenang dalam pemeriksaan dan terhindar dari segala bentuk tekanan, paksaan dan penyiksaan. Walaupun disadari bahwa kehadiran bantuan hukum itu mengakibatkan biaya bertambah mahal dan jalannya suatu perkara menjadi agak lama. Namun di pihak lain dapat pula menjamin hak asasi manusia. (Syafruddin, 2008 : 3-4 )

Saksi dan korban dalam peradilan pidana menempati posisi kunci, sebagaimana terlihat dalam penempatannya dalam pasal 184 KUHAP. Sebagai alat bukti utama, tentu dampaknya sangat terasa bila dalam suatu perkara tidak diperoleh saksi. Pentingnya kedudukan saksi dalam proses peradilan pidana, telah dimulai sejak awal proses peradilan pidana. Harus diakui bahwa terungkapnya kasus pelanggaran hukum sebagian besar berdasarkan informasi dari masyarakat. Begitu pula dalam proses selanjutnya, ditingkat kejaksaan sampai pada akhimya di pengadilan, keterangan saksi sebagai alat bukti utama menjadi acuan hakim dalam memutus bersalah atau tidaknya terdakwa. Jadi jelas bahwa saksi 
mempunyai kontribusi yang sangat besar dalam upaya menegakkan hukum dan keadilan.

Kedudukan saksi dan korban yang demikian pentingnya dalam proses peradilan pidana, nampaknya sudah disadari oleh pembuat undangundang perlindungan saksi dan korban. Hal ini dapat dibaca dalam konsideran undang-undang tersebut yang berbunyi:

a. bahwa salah satu alat bukti yang sah dalam proses peradilan pidana adalah keterangan saksi dan/atau korban yang mendengar, melihat, atau mengalami sendiiri terjadinya suatu tindak pidana dalam upaya mencari dan menemukan kejelasan tentang tindak pidana yang dilakukan oleh pelaku tindak pidana;

b. bahwa penegak hukum dalam mencari dan menemukan kejelasan tentang tindaki pidana yang dilakukan oleh pelaku tindak pidana sering mengalami kesulitan karena tidak dapat menghadirkan saksi dan/atau korban disebabkan adanya ancaman, baik fiisik maupun psikis dari pihak tertentu.

Bahkan dalam Pasal 37 sampai dengan 43 Undang-Undang Perlindungan saksi dan korban mengancam pidana bagi setiap orang yang melakukan kekerasan, pemaksaan atau cara apapun juga yang membuat saksi dan korban tidak bebas memberikian keterangan

. Dalam KUHAP, sebagai ketentuan hukum acara pidana di Indonesia, tersangka/terdakwa memiliki sejumlah hak yang diatur secara tegas dan rinci dalam suatu bab tersendiri. Sebaliknya bagi saksi, termasuk saksi korban, hanya ada beberapa pasal dalam KUHAP yang memberikan hak pada saksi, tetapi pemberiannya pun selalu dikaitkan dengan tersangka/terdakwa. Jadi hak yang dimiliki saksi dimiliki pula oleh tersangka/terdakwa, tetapi banyak hak tersangka/terdakwa yang tidak dimiliki oleh saksi.

Hanya ada satu pasal yang secara normatif khusus memberikan hak pada saksi, yaitu pasal 229 KUHAP. Yang memberikan hak kepada saksi untuk memperoleh penggantian biaya setelah hadir memenuhi panggilan di semua tingkat pemeriksaan

Menuurut Surastini Fitriasih (2009 : 3-4 ) bahwa dilihat dari sudut perundang-undangan, kedudukan saksi, termasuk korban berada dalam posisi yang lemah. KUHP misalnya, bahkan mengancam dengan pidana, saksi yang tidak datang ketika penegak hukum memintanya untuk memberikan keterangan. Apabila kita mencoba untuk membandingkan perlindungan hukum bagi saksi disatu pihak dan tersangka/terdakwa dipihak yang lain, mungkin kita akan sampai pada suatu pemikiran apakah hak-hak tersangka terdakwa diberikan karena kedudukannya yang lemah sehingga rawan abuse of power? Sementara saksi sebagai warga masyarakat, juga korban sebagai pihak yang langsung dirugikan kepentingannya, karena telah diwakili oleh negara yang berperan sebagai pelaksana proses hukum dianggap tidak perlu lagi memiliki sejumlah hak yang memberibn perlindungan baginya dalam proses peradilan. Sesungguhnya apabila kita cermati dalam kenyataannya, kondisi saksi tidak jauh berbeda dengan tersangka/terdakwa, mereka sama-sama memerlukan perlindungan, karena:

1. Bagi saksi (apalagi yang awam hukum), memberikan keterangan bukanlah suatu hal yang mudah.

2. Bila keterangan yang diberikan ternyata tidak benar, ada ancaman pidana baginya karena dianggap bersumpah palsu.

3. Keterangan yang diberikannya akan memungkinkan dirinya 
mendapat ancaman, terer, intimidasi dari pihak yang dirugikan.

4. Memberikan membuang waktu dan biaya

5. Aparat penegak hukum tidak jarang memperlakukan saksi seperti seorang tersangka/terdakwa.

Meskipun secara teoritis, saksi, terutama saksi korban telah diwakili kepentingannya oleh aparat penegak hukum,namun dalam kenyataannya mereka hanya dijadikan alat hukum untuk mendukung, memperkuat argumentasi untuk memenangkan perkara. Kemenangan aparat penegak hukum, dengan keberhasilannya membuktikan kesalahan terdakwa dan meyakinkan hakim mengenai hal itu, sesungguhnya juga merupakan kemenangan masyarakat (termasuk korban). Namun tidak jarang aparat penegak hukum mengabaikan pihak yang diwakilinya. Apakah korban merasa puas dengan tuntutan jaksa atau putusan hakim, misalnya, merupakan hal-hal yang tidak pernah diperhatikan. Manifestasi ketidakpuasan masyarakat terhadap perlakuan pihak yang mewakilinya, kemudian muncul dalam berbagai bentuk mulai dari tindakan pelemparan sepatu pada hakim, perusakan gedung pengadilan, sampai pada tindakan main hakim sendiri, yang akhir-akhir ini marak terjadi. Tindakantindakan anarki yang dilakukan masyarakat tersebut berpangkal tolak dati perasaan tidak puas, perasaan diperlakukan tidak adil dalam diri masyarakat.

\section{KESIMPULAN}

Perlindungan terhadap saksi dan korban pada prinsipnya harus merupakan pemberian seperangkat hak yang dapat dimanfaatkan dalam proses peradilan pidana. Perlindungan ini merupakan salah satu bentuk penghargaan atas kontribusinya dalam proses peradilan pidana demi untuk mencapai kebenaran materiil yang merupakan tujuan utama dari hukum acara pidana.

Perlindungan hukum terhadap saksi dan korban dalam proses peradilan pidana tidak hanya diperlukan pada saat sebelu saksi dan korban memberikan keterangannya di muka persidangan, akan tetapi juga sangat diperlukan sesudah memberikan keterangan di mukan persidangan, hal ini dimaksudkan untuk memberikan rasa aman dan percaya diri pada saksi dan korban.

Undang-Undang Nomor 13 Tahun 2006 tentang perlindungan saksi dan korban telah mengatur secara eksplisit tentang hak-hak saksi dan korban yaitu hak untuk : a) Memperoleh perlindungan atas keamanan pribadi, keluarga dan harta bendanya, serta bebas dari ancaman yang berkenaan dengan kesaksiannya yang akan, sedang, atau telah diberikannya; b) Ikut serta dalam proses memilih dan menentukan bentuk perlindungan dan dukungan keamanan; c) Memberikan keterangan tanpa tekanan; d) Mendapat penerjemah; e) Bebas dari pertanyaan yang menjerat; f)Mendapatkan informasi mengenai perkembangan kasus; h) Mendapat informasi mengenai putusan pengadilan; i) Mengetahui dalam hal terpidana dibebaskan; j)Mendapat identitas baru; k)Mendapat tempat kediaman baru; 1) Memperoleh penggantian biayatransportasi sesuai dengan kebutuhan; m) Mendapat nasihat hukum; dan/atau n) Memperoleh bantuan biaya hidup sementara sampai batas waktu perlindungan berakhir.

Kedudukan saksi dan korban dalam proses peradilan pidana adalah sangat strategis terutama dalam pembuktian di persidangan, karena menurut pasal 183 KUHAP pembuktian perkara pidana diperlukan minimal dua alat bukti ditambah keyakinan hakim. Saksi ditempatkan sebagai alat bukti pertama dan utama dalam proses perkara pidana. 
Dalam rangka efektivitas berlakunya Undang-Undang Nomor 13 Tahun 2006 maka disarankan kepada Presiden Republik Indonesia untuk segera mengeluarkan Peraturan Pemerintah tentang tata cara mengenai pemberian kompensasi dan restitusi terhadap korban pelanggaran hak asasi manusia yang berat dan ganti kerugian yang menjadi tanggung jawab pelaku tindak pidana.

\section{DAFTAR PUSTAKA}

Akrial, Zul. Kebijakan Perlindungan Hukum Terhadap Saksi dan Korban. Pekanbaru: Fakultas Hukum Unversitas Riau, 2008.

Barda Nawawi Arief, Bunga Rampai Kebijakan Hukum Pidana. Bandung: PT Citra Aditya Bakti, 1996a. Cetakan Pertama.

Fitriasih, Surastini, Perlindungan Saksi dan Korban sebagai Sarana Menuju Proses Peradilan (Pidana) yang Jujur dan Adil. Jakarta: Fakultas Hukum Universitas Indonesia, 2009.

Griffith, John. The Third Model of Criminal Process. 1970.

Harkrisnowo, Harkristuti, Perlindungan Saksi dan Korban Akses ke Peradilan. Jakarta: FHUI, 2003.

Iswanto, Yazid Effendi dan Angkasa, Viktimologi. Purwokerto: Penerbit Universitas Jenderal Soedirman, 1998. Cetakan Pertama.

L.H.C. Hulsman, Afscheid Van Het Strafrecht een Pleidooi Voor Zelfregulering, atau Selamat Tinggal Hukum Pidana Menuju Swa. Regulasi, Terjemahan Wonosutanto, Surakarta: Forum Studi Hukum Pidana, 1988. Cetakan Pertama. Jilid Kedua.
Made Darma Weda, Kriminologi. Jakarta: Raja Grafindo Persada, 1996. Cetakan Pertama.

Mardjono Reksodiputro, Kriminologi dan Sistem Peradilan Pidana. Jakarta: Pusat Pelayanan Keadilan dan Pengabdian Hukum (d/h Lembaga Kriminologi) Universitas Indonesia, 1994b. Cetakan Pertama (Edisi Pertama).

, Hak Asasi Manusia Dalam Sistem Peradilan Pidana. Jakarta: Pusat Pelayanan Keadilan dan Pengabdian Hukum (d/h Lembaga Kriminologi) Universitas Indonesia, 1994c. Cetakan Pertama (Edisi Pertama).

, Pembaharuan Hukum Pidana. Jakarta: Pusat Pelayanan Keadilan dan Pengabdian Hukum (d/h Lembaga Kriminologi) Universitas Indonesia, 1995. Cetakan Pertama (Edisi Pertama).

Muladi, Lembaga Pidana Bersyarat. Bandung: Alumni, 1985. Tanpa Cetakan.

, Kapita Selekta Sistem Peradilan Pidana. Semarang: Badan Penerbit Universitas Diponegoro, 1995. Cetakan Pertama.

, Hak Asasi Manusia, Politik dan Sistem Peradilan Pidana. Semarang: Badan Penerbit Universitas Diponegoro, 1997. Cetakan Pertama.

Packer, Herbert.L. The Limit of the Criminal Sanction. Califonia:Stanford University Press: 1968.

Syafruddin, Hak asasi Tersangka untuk mendapatkan bantuan hukum dalam system peradilan pidana, Fakultas Hukum USU, Medan 2008

Undang-Undang Nomot 13 Tahun 2006 tentang Perlindungan Saksi dan Korban 